\title{
Linkage between labor migration, remittance and self employed business activities in Nepal
}

\author{
Naveen Adhikari \\ Central Department of Economics, Tribhuvan University, Kathmandu, Nepal \\ nabueco@gmail.com
}

\begin{abstract}
This paper investigates the linkage between international labor migration, remittance and ownership of self employed business activities in Nepal using a nationally representative cross sectional data. The purpose of the paper is to test the hypothesis propounded by New Economics of Labor Economics. A two stage instrumental variable Probit model is used to assess the relationship between the variables. The findings suggest that household with migrant members is seven percent more likely to own an enterprise while impact of remittance is negligible and insignificant. This paper concludes that the skills and knowledge about technology acquired abroad by migrant labor could be instrumental for expanding the self employed business activities in Nepal contributing to overreaching objectives of poverty alleviation and creating jobs in the domestic market in the long run.
\end{abstract}

Keywords: International labor migration; Remittance; Self-employment; Business activities; Entrepreneurship

\section{Introduction}

Individual characteristics and capabilities, social cultures, economic barriers, and institutional provisions are important determinants for start up and expansion of business enterprises (Berger et al., 1998; Wagner, 2005; Aidis, 2005). Schoof (2006) identifies i) socio-cultural attitudes towards youth entrepreneurship; ii) entrepreneurship education and access to finance/ start-up financing; iii) conducive administrative and regulatory frameworks to promoting youth entrepreneurship; and iv) business assistance and support as major bottlenecks for starting up enterprises especially by the youth. In addition, insufficient capital to start up a business or expand the business activities is one among the major economic barriers to develop entrepreneurship in the developing world (Carpenter \& Peterson, 2002). The argument is more appealing in the context of developing countries where the credit and insurance markets are imperfect and incomplete. Under such imperfections, a prospective entrepreneur may not be able to borrow fund due to inadequate access on credit facility, high transaction cost and collateral issues; while missing insurance market does not suffice them minimizing loss in case of failure (Aghion, et al., 2005). Therefore, the household or individual access to the financial resources is very much important for starting and expanding business activities in the developing countries like Nepal.

Ideally, remittances are expected to ease the financial constraints for both consumption and investment purposes. New Economics of Labor Migration (NELM) supports the notion that households with low income or vulnerable to sudden external shocks, like crop failures, consider migration as a strategy to mitigate and cope with such external shocks (Stark \& Bloom, 1985). Therefore, the money that is remitted back home is used to abate risks, arising out of those external shocks. However, the household may mobilize the surplus amount-residual remittanceincome after fulfilling their consumption needs - in asset accumulation and investment. In addition, social remittance (knowledge, skills, attitude towards work) acquired abroad can

Review History: First manuscript submitted June 29, 2016; Submission of first revised version April 4, 2017; Submission of second revised version August 30, 2017; Accepted September 1, 2017. 
provide further impetus for start up of business in home-country either through transmitting knowledge to family members or engaging themselves after they return back home. Migrant workers generally come into contact with techniques and technologies that are more advanced in nature than that of their home region (Leonard, 2000). It can accordingly contribute through workers' remittances, transfer of capital, skills, knowledge, technology and investments by trans-national communities in starting up businesses (Schoof, 2006). The World Bank (2013) found that a higher-than-average number of returnees choose self-employment and entrepreneurial activity.

In Nepal, migration and money remitted back home is increasing. Though migration, particularly seasonal migration to India, was common in the past (Seddon et al., 2002), the growth of migration accelerated in the last two decades when Nepal revamped several policies of opening up and liberalizing the economy. The trend of migrating from Nepal to other countries is ever increasing, as domestic economy beset with few employment opportunities on manufacturing and industry sector and low agricultural productivity (NRB, 2013). Persistent and widespread socio-economic inequality and a decade long conflict were the fueling factors for both internal as well as external migration (Sharma et al., 2014). Unprecedented use of natural resources and rapid growth of construction sectors in the Middle East, where the wage rate ('pull factor') is better than in India, attracted Nepalese workers, mostly for low and medium-skilled jobs (Tuladhar, et al., 2014).

Today about 1300 youths leaves the country daily; and the money they remit back accounts about 28 percent of GDP in 2015 (DoFE, 2015). Remittance has been indeed the life line of Nepali economy; and its share to the economy is marginally less than that of agriculture sector (32\%). The growing remittance income is now larger than official development assistance (ODA) and foreign direct investment (FDI) combined (MoF, 2015). The remittance in 2004/05 was about 65 billion, accounting nearly 11\% of GDP; which has grown exponentially both in terms of value and share to GDP over the years. In 2015, it is estimated to reach 620 billion - nearly 10 times - within a decade and has a volume of about 29 percent of the GDP. Since 2005 (except for 2009 and 2012, when the global financial crisis and the Euro zone sovereign debt crisis affected the demand for labor in the Middle East), overseas migration for employment has been growing at around 20\% annually. So far the destination concerns, Malaysia, Qatar, Saudi Arabia and UAE together have absorbed about $85 \%$ of the total Nepalese migrant workers (Sapkota, 2013; Tuladhar et al., 2014).

The implication of such growing remittance inflow in the country has been to the ever expanding trading sector. This is also evident from the fact that service sector has been growing more than average which is mostly remittance fed. The average growth rate of service sector has been around 4.5 percent for last decade; and clear linkages between remittance growth and service sector growth can be inferred though with some lags (MoF, 2015). The import based trading services has increased which obviously have the implications for business activities in the country.

The surge of remittance inflow in recent years results into a noticeable decline in poverty from about $31 \%$ in $2003 / 04$ to $25 \%$ in $2010 / 11$. Despite such impact, there are concerns over productive utilization of the remittances (MoF, 2014). CBS (2011) estimates that out of total remittances; 79 percent is spent on daily consumption followed by loan repayment ( 7 percent), household property (5 percent) and education ( 3 percent). This pattern indicates that there is a considerable implication of remittance on the livelihood of people, as a major portion of remittance is spent on consumption. Besides, remittance has played vital role in maintaining external macroeconomic stability of Nepal since last decade (NRB, 2013).

In addition to impact of remittance in particular for household livelihood, it has also implications for business activities through production and consumption. The returnee migrants are now engaged especially in productive agricultural activities or engaged in service sector where trade of imported goods and services is dominant. Devkota (2015) has listed some of the returnee migrants who got success on business, which they started with the knowledge they acquired aboard. The World Bank (2013) has also found interesting cases of returnees: Being self employed in business activities, returnees has explored barriers, and opportunities of carrying out business in Nepal. It is also found that macroeconomic impacts of the labor migration and remittances has been conducive for business activities in Nepal through increased aggregate demand in economy (Adhikari \& Katuwal, 2015). 
Given that labor migration and remittance could be instrumental for growth and development of enterprises, this paper aims to test the NELM hypothesis that how far labor migration and remittances matters for enterprise development. Therefore, the objective of the paper is to examine nexus, using a household level data, between labor migration, remittance and emergence of self employed business opportunities in Nepal. Our findings suggest that knowledge, skill and their exposure to better working environment has implication for business ownership than the money they remit back. This will have long run implication in Nepal not only for enterprise growth but also for self employment and creating more jobs in the domestic market.

\section{Review of literature}

The impact of labor migration and remittance on the various facets of economy is mixed and controversial. These differences are observed both in theory and practice. Hass (2010) provides reviews of theories that are classified as those who favor migration and remittance with optimism and those who oppose these with pessimism. Among different theories, New Economics of Labor Migration (NELM) provides a framework and linkage explaining how migration and remittance could impact household decision. One of the unique features of NELM is that migration occurs as they not only migrate to maximize expected income but also to minimize the risks that could arise from sudden drop in income or production. Following the pioneering works of Stark and Bloom (1985) and Stark and Levhari (1982), which gave rise to NELM, a number of researchers have attempted to unravel the economic implications of international migration on the developing countries (Jadotte, 2009). The theoretical foundation for this route of migration is discussed on paper by Stark (1991). He hypothesized that migrants play the role on financial intermediaries enabling the rural households to overcome credit and risk constraints on their ability to achieve the transition from familial to commercial production. The NELM is the only migration theory that explicitly links the migration decision to the impacts of migration, with remittances being this link (Taylor \& Fletcher, 2001). According to the NELM a household maximizes joint income, status and minimizes risks.
The empirical evidence of impact in various facets of the economy is also mixed. A large quantum of literature is available on impact of labor migration and remittance in agriculture for the obvious reasons that agriculture remains main stay of large segment of the population in developing worlds. Rozelle et. al. (1999) examined impact of labor migration and remittance on paddy production taking a case of rural china where he found that labor migration in short run caused the fall in paddy yield but it was compensated by easing the financial constraints of the household allowing them to buy capital or technological equipments thereby increasing productivity in the longrun. While this early paper shows a positive impact of remittance in long run, De Brauw (2010) examining the seasonal migration in Vietnam and its impact on input demand, however, found no impact of migration and remittance on the agriculture sector. In Nepalese context, Adhikari (2014) also found that out labor migration has caused the fall in productivity in potato and maize yield in Nepal but the compensating relationship of remittance with yield is ambiguous and unclear. Tuladhar et al. (2014) have also found similar results in paddy production - a loss paddy yield due to out labor migration but no compensating role of remittance as large chunk of remittance is still going for consumption. In similar paper, While there is sufficient literature on examining impact of labor migration and remittances on agriculture using a household level data, much of the studies that examines the nexus between migration, remittance and investment are macro in nature. Also, available literatures have examined use of remittance on productive business activities rather than assessing the impact of labor migration and remittance for entrepreneurship growth and development. Most of these studies support that remittance is used for consumption and in general about three-quarters of their repartriated earnings are used on consumption (Durand et al., 1996; and Amuedo-Dorantes and Pozo, 2006). Some even argue that remittances are spent of status oriented goods (Chiami et al., 2003). That means, most of the returnee migrants uses their money in purchase of housing, land and holding of other precious metals or ornaments. In Nepal too, Parajuli Thapa (2013) has found that remittance is more consumed than investment and he argued that Nepal is exporting cheap labor at the cost of domestic production. 
There are limitations of available literature in terms of research desing - they use perception basined qualitative research design to examine the link between migration and remittance rather than quantifying the impacts. First, they do not consider the substitution effect that households may have with increased remittance income as other sources of household income may be directed toward the productive investment. Secondly, spending like on housing, consumer durables is not a frequent phenomenon rather the household may choose to divert resource to productive investment in the event the migrants stay aboard for long and remits back money in regular interval. Some of the studies have found a positive association between remittance and entrepreneurship. For example, Funkhouser (1992) finds that remittances are meant to increase in self-employment. Given the association of self-employment with complementary capital investments, it follows that remittances may be contributing to business ownership (AmuedoDorantes \& Pozo, 2006). In this regard, McCormick and Wahba (2001) and Dustmann and Kirchkamp (2002) find that Turkish and Egyptian return migrants have a comparative advantage in entrepreneurial activity, which may possibly be linked to their importation of both human and financial capital. Woodruff and Zenteno (2007) agreed that remittance helped as capital to expand micro-enterprises in Mexico. Regarding the determinants of entrepreneurship, Kilic et al. (2009) also noted that there is a positive relationship between return migrants and business ownership in Albania but business investment is in the non-farm sector. Recently, Devkota (2015) has examined the relationship based on the primary survey data conducted at three districts of Nepal and found those households and individual characteristics; and the networking effects as major determinant of returnee migrants for starting up a business rather than remittance as such. Amidst such literatures are available, this study will further provide evidence in examining the nexus between labor migration, remittance and entrepreneurship at household level.

\section{Data and methods}

\subsection{Conceptual framework}

Figure 1 provides the basic framework for exploring the linkage between migration and remittance with ownership of enterprise. This is based on hypothesis propounded by New Economics of Labor Migration. This framework provides two channels in exploring why migration and remittance should matter for start of an enterprise. First, the money that migrant remit to their home will ease the financial constraints faced by the household which in turn increases the likelihood of starting or expanding business activities. Second, migrants would be exposed to better technology, skills and working culture as compared to their home; which in turn helps household to opt for business enterprise.

\subsection{Empirical model}

In line with conceptual framework, the empirical strategy is to see impact of migration and remittance in ownership of business enterprise. Since the objective of the paper is to examine the nexus between labor migration, remittance and entrepreneurship taking ownership of enterprise as proxy of entrepreneurship. As household can be observed having/owning a business activities or not - therefore obvious candidate model in our case is logit or probit due to binary nature of the dependent variable. Accordingly, the model can be formulated as

$$
\operatorname{Pr}(\mathrm{B}=1)=\mathrm{F}\left(\mathrm{M}_{\mathrm{i}}, \mathrm{REM}_{\mathrm{i}}, \mathrm{Z}_{\mathrm{i}}\right)
$$

where $B$ is ownership of business, $M$ is the migration dummy, REM is the remittance received by the household, and $\mathrm{Z}$ include the other socio-economic, households and individual characteristics that affect the ownership of self employed business, i indexes household.

Here, the variables of interest are migration status (whether household has a migrant member in the house) and remittance they received during last year as captured in NLSS. The model further controls other variable like household's human capital status, demographic characteristics, access to information and market. One of the important variables is the family human capital position for which we have taken the education of the household head. The demographic information like sex of the household head, family size, size of dependent members like children and old members in family are taken to capture the household characteristics. Likewise the land size has been taken for wealth indicators as it could be possibly associated with collateral issues along with whether the particular 
household has taken the loan or not are used as further control variable. The household access and use of information is controlled using Radio as control variable. Since geographical variations in terms of different development regions or ecological belts matter in Nepal, there are taken as explanatory variable along with rural urban dummy.

However there is issue of endogeneity for several reasons in equation (1). First, migration and ownership of enterprise could be simultaneously determined. For example, a household with business has better income that enable member of household to choose for migration by easing liquidity constraint that household faces to cover the cost associated with migration of its family member. Second, there are certain unobserved factors that determine whether household is engaged in business activities and these factors basically include the history of families whether they were engaged in business activities in the past and ability to take risks. Since such factors are not well captured by the NLSS, it is difficult to include as control variable in the model. Third, remittance itself is function of migration. To overcome these limitations, econometric method suggests for the use of instrumental variables (Wooldridge, 2009). Accordingly, this paper uses a two stage Probit model with instrumental variable to address the econometric issues arising out of endogeneity problems. The instrumental variable must be chosen such that it affects endogenous variable but not the outcome. The

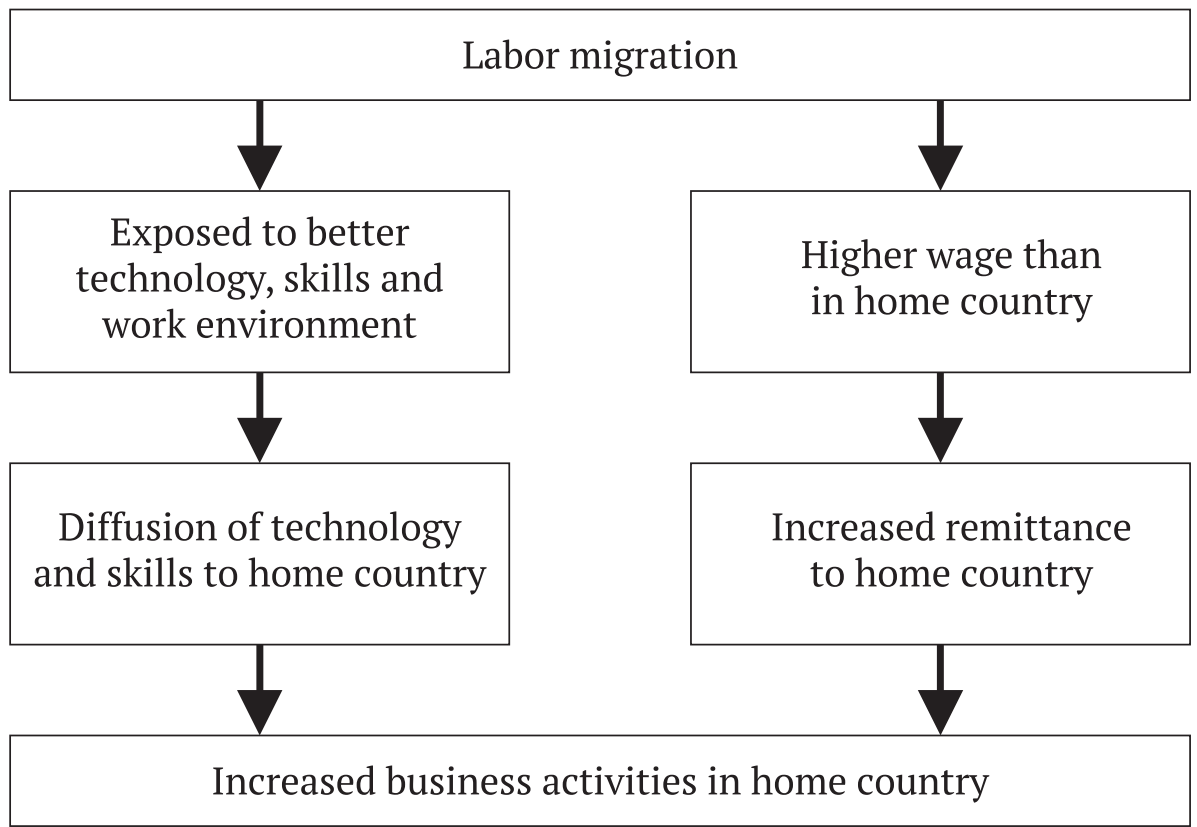

Figure 1. Linkage between labor migration, remittance and business activities 
literature in migration and remittance shows use of networking as the primary candidate for the instrument (Rozelle et al., 1999, De Brawu, 2010). This paper uses similar instrument and in particular number of migrants in the primary sampling unit has been taken as instruments to remove the biases.

The basic structure of the equation for empirical estimation is given in (2). This equation is further instrumented for endogeneity. The definition of the variable used in equation are provided in Table 1.

$$
\begin{aligned}
& \mathrm{P}(\mathrm{B}=1)=\beta_{0}^{\prime}+\beta_{1}^{\prime} \mathrm{M}+\beta_{2}^{\prime} \mathrm{REM}+\beta_{3}^{\prime} \mathrm{HH}+ \\
& \beta_{4}^{\prime} \mathrm{SEX}+\beta_{5}^{\prime} \mathrm{CH}+\beta_{6}^{\prime} \mathrm{OLD}+\beta_{7}^{\prime} \mathrm{EDU}+ \\
& \beta_{8}^{\prime 4} \mathrm{AGE}+\beta_{9}^{\prime} \mathrm{LS}+\beta_{10}^{\prime 6} \mathrm{LOAN}+\beta_{11}^{\prime} \mathrm{RADIO}+ \\
& \beta_{11}^{\prime} \text { URBAN }+\beta_{12}^{\prime} \text { TIME }+\beta_{11}^{\prime} \text { MOUNTAIN + } \\
& \beta_{12}^{\prime \prime} \mathrm{HILL}+\beta_{13}^{\prime} \mathrm{EDR}+\beta_{14}^{\prime} \mathrm{CDR}+\beta_{15}^{\prime} \mathrm{WDR}+ \\
& \beta_{16}^{\prime 2} \mathrm{MWDR}+\mathrm{u}
\end{aligned}
$$

Here $\mathrm{u}$ is the stochastic term. The dummies Mountain and Far Western Development Region (FWDR) are taken as reference categories in the model.

\subsection{Data}

Third round of Nepal Living Standard Survey $(\mathrm{NLSS})^{1}$ data has been used in the study. It is a nationally representative survey conducted flowing a globally adopted framework and methodology developed by World Bank. Central Bureau of Statistics (CBS), Government of Nepal has been carrying out Nepal Living Standards Survey (NLSS) since first time in 1995/96 and third round was conducted in 2010/11. NLSSIII provides cross section sample about 5,988 households. The information collected here are rich in terms of coverage and it covers various information like household information, access to facilities, economic activities and engagement, consumption and income, access to financial market, migration and remittance which is divided into 17 difference sections. Therefore, the basis for analysis on this paper is the cross sectional household information consisting 5988 observations. However, the paper is based on only 5371 observations - part of which were lost during the data cleaning process as there were many missing case for the variables used in empirical specification.

\section{Results and discussion}

\subsection{Ownership of enterprise in Nepal}

Table 2 and 3 presents a status of enterprise ownership in Nepal. NLSS defines self employed if a household is said to be operating a non-farm enterprise if any member of that household reports to be self employed in a non agricultural activity (CBS, 2011). The proportion of households engaged in self employed non-farm activities are reported in Table 2 .

It is found that proportion of self employed activities is increasing over the years. About $24 \%$ of the households were found having self owned business in 1995/95 which increases further to $28 \%$ in $2003 / 04$ and is about $35 \%$ in 2010/11. Among these, share of trade as sector of engagement account about 36\% closely followed by manufacturing $35 \%$. Nearly half of those engaged in trade and manufacturing are found engaged in service sector (16\%). In terms of legal status of operation, the informal or unregistered enterprises are dominant. For example, only about $16 \%$ of total business enterprises are found to be registered (Table 2).

Further there are variations in terms of geography, rural urban and income status of the household measured by consumption quintile. About $38 \%$ of households from Central Development Region were found to own enterprise closely followed by Eastern Development Region (36\%). The far western region has about $27 \%$ less than those of Western (31\%) and Far West (27\%). Interestingly, the household form mountain (41\%) seems to own the business enterprise which is more than Terai (37\%) and Hill (32\%). The higher proportion in Mountain could possibly because of low agriculture land available for agricultural or farm activities. Similarly, about $42 \%$ of urban households own business enterprise compared to rural (30\%). In terms of wealth status, richer are found owning business enterprise compared to households from lower stratum. About $42 \%$ from top consumption quintile were found to own the enterprise as compared to $32 \%$ of lowest quintile. In addition, there are also variations in terms of sector of engagement though manufacturing and trade are dominant across the categories (Table 3).

\footnotetext{
${ }^{1}$ Author has purchased the NLSS data set from Central Bureau of Statistics (CBS), Government of Nepal
} 
Table 1. Description of variables

\begin{tabular}{ll}
\hline Name of the variables & Description \\
\hline Business Ownership (B) & Dummy variable 1 if household owns any kind of self employed business \\
Remittance (REM) & Dummy variable- 1 if a household has at least one migrant labor abroad \\
& $\begin{array}{l}\text { Total remittance received by Households (Cash and Kind) during last } \\
\text { year }\end{array}$ \\
Household Size (HH) & Number of Family Members in a households sharing same kitchen for last \\
& 6 months \\
Children (CHILD) & Number of family members with age between 15-60 years \\
Old (OLD) & Number of family members with age more than or equal to 60 \\
Education (EDU) & Years of Schooling of Household head \\
Age (AGE) & Age of the Household head \\
Land Size (LS) & Total Area of Land owned by Household for cultivation (in hector) \\
LOAN & Dummy -1 if household is observed to take loan from either (formal or \\
RADIO & informal) sources \\
URBAN & Dummy - 1 if household has radio at home \\
TIME & Dummy -1 if household is from urban area \\
HILL & Time taken to reach the nearest market center in Minutes \\
TERAI & Dummy 1 if household belongs to Hill \\
MOUNTAIN & Dummy 1 if household belong to Terai \\
EDR & Dummy 1 if household belong to Moutain \\
CDR & Dummy- 1if household belongs to EDR \\
WDR & Dummy-1 if household belong to CDR \\
MWDR & Dummy-1 if household belong to WDR \\
FWDR & Dummy -1 if household belongs to MWDR \\
MIG_PSU & Dummy- 1 if household belongs to FWDR \\
\hline
\end{tabular}

\subsection{Summary statistics of the variables used in the} model

Table 4 provides the summary statistics of the variable used for the study. It was found that about 35 percent of households owned the business in the sample ${ }^{2}$. Remittance that particular household receives averaged around 99302 per annum considering both cash and kind and found to range from Rs. 1000 to 1 million with standard deviation of 133072 . NLSS reports average remittance received by a household of NRs 58335 remittance (CBS, 2011). While same report does not provide the figures in maximum or minimum, the amount estimated here is different as we have taken the amount only for those who have migrated abroad and excludes those who receive remittance from within Nepal. Given the large variation in remittance, the median annual remittance amount remitted annually is Rs. 55000. About $32 \%$ of the households were seen to have at least a member migrating abroad. This is indeed the proportion of the households having a member migrating abroad and it excludes migration within country. The proportion of households having at least

\footnotetext{
${ }^{2}$ The proportion and figures might not match with NLSS due to sample size and sampling weights. Figures reported in this study are not corrected for household or individual weights.
} 
one member migrating both within and outside country is as high as of 51\% (CBS, 2011).

The average household size is found to be 4.76 ranging from a single member to as high as of 20 members. The average size of children (with age less than 15 years) stands to be 1.68 while that of old (with age more than equal to 60) was found to be less than 1 . The average years of schooling by household head is found to be 6.44 ranging to a maximum of 16 years. The average land owned by the household is 0.47 hectares. About 62 percent of households have taken the loan from both formal and informal sources. High proportions (86\%) of households have the radio. It takes about 46 minutes to reach the nearest market center.

In terms of geographical area and place of their residence, about 35 percent of the households were found to be of urban area. The proportion of households living in Hill are 54\% followed by 40 percent in Terai. Likewise, 38\% were from Central Development Region followed by Eastern (21\%), 19\% from Western and 13\% from Mid Western development regions (Table 3).

Table 2. Status of self-employed business activities in Nepal (in \% of households)

\begin{tabular}{llll}
\hline & $\mathbf{1 9 9 5 / 9 6}$ & $\mathbf{2 0 0 3 / 0 4}$ & $\mathbf{2 0 1 0 / 1 1}$ \\
\hline $\begin{array}{l}\text { Households with enterprises } \\
\text { Major Sector of Engagement }\end{array}$ & 24.2 & 28.2 & 34.6 \\
Manufacturing & 29.9 & 30.8 & \\
Trade & 52.1 & 31.7 & 35.4 \\
Service & 14.3 & 29.2 & 36.1 \\
Registered Enterprise & 11.7 & 19.6 & 16.6 \\
\hline
\end{tabular}

Source: NLSS III, CBS (2011)

\subsection{Empirical results}

Table 5 reports the results from Two Stage Probit model with instrumental variable as discussed in methodology section. The overall fitness of the model is found satisfactory as given by Wald Chi square value which is significant at $1 \%$. The Wald test of exogeneity further rejects the null hypothesis of no endogeneity. That means, the use of instrumental variable is justified here and simple use of probit model could lead to inefficient estimates of the impact.

Several control variables were found significant. There is positive association between ownership of enterprise and household size indicating that household with more family members are likely to start a business. This could possibly be livelihood diversification strategy of the household as with more members households have more choice for allocation of their family members for different economic activity. Analogously, the coefficient of children and old are negative though only coefficient of children was found significant. This suggests that households having more dependent population are less likely to own an enterprise. This fact is well established in economic literature as having more dependent family members reduces time available for working members along with increased cost of care of those dependent members. As expected in theory, the years of schooling by household head is positive and significant indicating that household with higher years of schooling are more likely to own the enterprise. This is quite expected as education household head can better access the information and may also better assess the risks associated with operating an enterprise. Likewise, the coefficient of age is found positive but insignificant. This indicates that household head with more experiences (more age) are more likely to own the enterprise but there is no strong evidence for this in the data as reflected by insignificant coefficient. The land size which shows both households wealth status and ability to borrow the funds is not found significant determinant of the business in Nepal.

In terms of indicators for access to information and market, both coefficients are found 
Table 3. Distribution of business enterprise in Nepal (in \% of households)

\begin{tabular}{|c|c|c|c|c|c|}
\hline \multirow[b]{2}{*}{ Categories } & \multirow{2}{*}{$\begin{array}{l}\% \text { of } \\
\text { Enterprise }\end{array}$} & \multicolumn{4}{|c|}{ Sector of Engagement (\%) } \\
\hline & & Manufacturing & Trade & Services & Others \\
\hline \multicolumn{6}{|c|}{ Development Regions } \\
\hline Eastern & 36.4 & 27.8 & 43.7 & 14.9 & 13.7 \\
\hline Central & 37.6 & 37.9 & 31.6 & 20.2 & 10.4 \\
\hline Western & 31.1 & 36.8 & 41.4 & 12.6 & 9.2 \\
\hline Mid West & 33.3 & 38.7 & 28.6 & 16.4 & 16.4 \\
\hline Far West & 27.3 & 39.7 & 33.7 & 15.2 & 11.5 \\
\hline \multicolumn{6}{|c|}{ Ecological Belts } \\
\hline Mountains & 41.7 & 44.4 & 22.7 & 19.6 & 13.4 \\
\hline Hills & 32.0 & 42.8 & 31.8 & 15.1 & 10.1 \\
\hline Tarai & 37.0 & 27.5 & 42.2 & 17.4 & 12.8 \\
\hline \multicolumn{6}{|l|}{ Urban/Rural } \\
\hline Urban & 42.1 & 24.7 & 44.5 & 23.3 & 7.5 \\
\hline Rural & 30.6 & 39.4 & 33.0 & 14.1 & 13.4 \\
\hline \multicolumn{6}{|c|}{ Consumption Quintile } \\
\hline Poorest & 24.0 & 50.4 & 24.3 & 9.9 & 15.5 \\
\hline Second & 29.0 & 35.6 & 32.9 & 14.6 & 17.0 \\
\hline Third & 32.6 & 38.7 & 35.8 & 14.1 & 11.4 \\
\hline Fourth & 36.0 & 40.3 & 33.4 & 14.5 & 11.8 \\
\hline Richest & 42.0 & 25.2 & 43.5 & 22.7 & 8.6 \\
\hline Nepal & 34.6 & 35.4 & 36.1 & 16.6 & 11.7 \\
\hline
\end{tabular}

Source: NLSS III, CBS (2011)

statistically significant. For example, household having Radio are more likely to own the enterprise and coefficient of radio is significant at $0 \%$. The distance to the market is negatively related with ownership of enterprise - coefficient of enterprise is also significant at $0 \%$. This is possibly because of high cost of transportation for doing business. Similarly, the access to credit market also matters. The coefficient of loan in the equation is statistically significant at $0 \%$ suggesting that household with borrowing are $17 \%$ more likely to own the enterprise.

With respect to place of residence, only the coefficients of rural/urban and mountain were found significant. Households residing in urban area are $28 \%$ more likely to own enterprise. This is quite natural as business activities takes place in urban area significantly higher than rural.
Surprisingly, the people from Hill and Terai are less likely to own a business as compared to mountain. While control for other factors, it is quite surprising to find negative coefficient of Hill and Terai. This indicates that there is less likely of owning enterprise compared to mountain. However it commensurate with fact that most of enterprise in sample were from Mountain area. The results also suggest that development regions do not matter for the ownership of enterprise. These in general indicate the place of enterprise is less important in determining whether household owns an enterprise.

The coefficients of interest namely migration dummy and remittance received by household shows the expected sing but only migration status is found significant. The coefficient of migration dummy is statistically significant at 
Table 4. Summary statistics of the variables used

\begin{tabular}{lllll}
\hline Variable & Mean & Std. Dev. & Min & Max \\
\hline Business & 0.35 & 0.48 & 0.00 & 1.00 \\
Remittance & 99302.37 & 133072.00 & 1000.00 & 1000000.00 \\
Migration Status & 0.28 & 0.45 & 0.00 & 1.00 \\
Household Size & 4.76 & 2.31 & 1.00 & 20.00 \\
Children & 1.68 & 1.52 & 0.00 & 11.00 \\
Old & 0.42 & 0.68 & 0.00 & 4.00 \\
Years of Schooling & 6.44 & 5.04 & 0.00 & 16 \\
Age & 46.00 & 14.13 & 11.00 & 95.00 \\
Land & 0.47 & 0.94 & 0.00 & 24.40 \\
Loan & 0.62 & 0.49 & 0.00 & 1.00 \\
Radio & 0.86 & 0.34 & 0.00 & 1.00 \\
Time & 46 & 32.03 & 0.00 & 260 \\
Urban/Rural & 0.35 & 0.48 & 0.00 & 1.00 \\
Hill & 0.54 & 0.50 & 0.00 & 1.00 \\
Terai & 0.40 & 0.49 & 0.00 & 1.00 \\
EDR & 0.21 & 0.41 & 0.00 & 1.00 \\
CDR & 0.38 & 0.49 & 0.00 & 1.00 \\
WDR & 0.19 & 0.39 & 0.00 & 1.00 \\
MWDR & 0.13 & 0.33 & 0.00 & 1.00 \\
\hline & & & & \\
\hline
\end{tabular}

$1 \%$ and value of coefficient shows that household with migration are $7 \%$ more likely to own the enterprise. While remittance is insignificant despite its sing is as per expectation of NELM hypothesis. This would mean that out of two channels that could impact the ownership of enterprise, the social capital seems influencing weather household owns the business enterprise or not. The remittance that is expected to ease the financial constraints has yet to show the impact. However, these results should be understood in a specific context. First, in absence of historical information about enterprise like when household started a business, the cross section data may fail to capture those historical factors. This could possibly be traced using panel data $^{3}$. Second, impact of remittance has time varying properties specially with regard to use of it. For example, the money remitted at early stage could possibly be used in consumption and repaying loan. The household may further think of accumulating fixed asset like purchase of land or invest in human capital. The subsequent lot of remittance may be used in investment for earning purpose. Since data could not capture number of times that household has remittance received over the years, and this could be the reason that effect of remittance is coming insignificant. Third, whereas it is expected that migrant member might have disseminated the knowledge or skills or technology acquired aboard to the household member, the channel for which is still unclear and less explored. This could possibly be traced with information about returnee migrant but such information is not available in the data set used.

Despite these considerations, a number of implications can be drawn from these results. As expected the remittance has no impact on owning the business - contrary to the NELM hypothesis that it will ease the household financial

\footnotetext{
${ }^{3}$ Despite NLSS methodology mention for panel data collection, panel data is not available from CBS in public domain.
} 
constraints enabling household to investment on enterprise activities. The remittance is yet to show its impact as either magnitude of remittance is low or households have other priorities compared to start of an enterprise. This is similar to findings that a large chuck of total remittance received goes for general consumption and asset accumulation. However, alternative channel of impact of labor migration seems working for starting up business - the channel of knowledge and technology diffusion. This is quite important from policy prospective as Government of Nepal has been trying to develop strategy to retain the migrant worker that has better knowledge, skill, technology and of course the money. The findings from this paper further supports that returnee migrant could be potential source for enterprise development in country.

\section{Conclusion}

Using a household level data, this paper examined whether labor migration and remittance has been instrumental on starting and expanding the business activities in Nepal. A two step instrumental variable Probit model has been used to examine the relationship. The empirical findings suggest that a household with a migrant worker has positive and significant impact on the ownership of the business. In particular, there is 7 percent more likely that a household having a migrant worker owns a

Table 5. Two-stage probit model with instrumental variable

\begin{tabular}{|c|c|}
\hline Variables & $\begin{array}{l}\text { Dependent variable } \\
\text { (Business ownership) }\end{array}$ \\
\hline Remittance (Remittance Received in NPR) & $6.23 \mathrm{e}-07(6.12 \mathrm{e}-07)$ \\
\hline Migration Status ( 1 if household has at least one migrant member abroad) & $0.068 * * * * 0.0501)$ \\
\hline Household Size & $0.180 * * * *(0.0213)$ \\
\hline Children (Number of Members with age less than 15 years) & $-0.225^{* * * *}(0.0323)$ \\
\hline Old (Number of Members with age more than 60 years) & $-0.0952(0.545)$ \\
\hline Education (Years of Schooling of Household Head) & $0.037 * * * *(0.0024)$ \\
\hline Age (Age of Household Head) & $0.014(0.15)$ \\
\hline Land Size (Land size in Hectares) & $-0.0219(0.0265)$ \\
\hline Loan (1 if household has borrowed loan) & $0.169^{* * * *}(0.0639)$ \\
\hline Radio (1 if household owns a radio) & $0.045 * * * *(0.001)$ \\
\hline Time (Time in minuets taken to reach nearest market center) & $-0.037 * * *(0.002)$ \\
\hline Urban (1 if household is from urban area) & $0.281 * * * * 0.0731)$ \\
\hline Hill (1 if household is from hill) & $-0.389^{* * * *}(0.117)$ \\
\hline Terai (1 if household is from Terai) & $-0.206(0.126)$ \\
\hline EDR (1 if household is from Eastern Dev. Region) & $0.120(0.146)$ \\
\hline CDR (1 if household is from Central Dev. Region) & $0.118(0.130)$ \\
\hline WDR (1 if household is from Western Dev. Region) & $0.0834(0.129)$ \\
\hline MWDR (1 if household is from Mid Western Dev. Region) & $0.0747(0.158)$ \\
\hline Constant & $-0.783^{* * * *}(0.153)$ \\
\hline Observations (n) & 5371 \\
\hline Wald $\operatorname{chi}^{2}(14)$ & 128.86 **** $(0.00)$ \\
\hline Wald test of exogeneity $\operatorname{chi}^{2}(1)$ & $3.29 * *(0.05)$ \\
\hline
\end{tabular}


business. However, surprisingly, there is no evidence of impact of remittances on starting up the business. The relationship also suggests that other variables also matter for starting up business. The possible route of explaining this phenomenon could be the migrant's exposure to better working environments and technology thereby enhancing their skills. The insignificant remittance implies that it is going for consumption and perception based survey results at still 80 percent of remittance is used for consumption purposes.

The findings has important bearing that knowledge, skills and knowhow that migrants labor earns abroad could be instrumental for starting up or expanding business activities in Nepal. This in longer term could be helpful on generating self employed business and creating employment opportunities in the country itself.

\section{Acknowledgments}

The feedback and comments received from 3 anonymous reviewers greatly helped me to enrich the content and quality of this article. I would also like to acknowledge editor(s) of journal and my colleagues-Khagendra Katuwal and Tulasi Nepal for reading manuscript and providing important feedback.

\section{References}

Adhikari, N., 2015. Labor Migration, Remittance and Technological Adaptation in Nepalese Agriculture Conference Proceeding, 2nd International conference on Economics and Finance. Nepal Rastra Bank, Kathmandu.

Adhikari, N., Katuwal, K., 2015. Channelizing Remittance for Productive Use. Shodhashala Center for Research and Policy Studies, Kathmandu.

Aghion, P., Burgess, R., Redding, S., Zilibotti, F., 2005. Entry liberalization and inequality in industrial performance. Journal of the European Economic Association 3, 291-302.

Aidis, R., 2005. Entrepreneurship in transition countries: A review. Centre for the Study of Economic and Social Change in Europe, London.

Amuedo-Dorantes, C., Pozo, S., 2006. Migration, remittances, and male and female employment patterns. The American economic review 96, 222-226.

Berger, A.N., Udell, G.F., 1998. The economics of small business finance: The roles of private equity and debt markets in the financial growth cycle. Journal of banking \& finance 22, 613-673.

Carpenter, R.E., Petersen, B.C., 2002. Is the growth of small firms constrained by internal finance?. The Review of economics and Statistics 84, 298-309.

CBS, 2011. Nepal living standards survey 2010/2011. Central Bureau of Statistics, Kathmandu.

De Brauw, A., 2010. Seasonal migration and agricultural production in Vietnam. The Journal of Development Studies 46, 114-139.

De Haas, H., 2010. Migration and development: A theoretical perspective. International migration review 44, 227-264.

Devkota, J. N., 2015. Migration and Development: Impact of Migrants' Remittance on Poverty, Inequality and Entrepreneurship in Nepal. Retrieved from http://ir.nul.nagoya-u.ac.jp/jspui/ simple-search?query=Jeevanath $+\&$ submit $=$ Go accessed on 5th November 2016.

DoFE, 2015. Labor Migration for employment status report 2014/15. Department of Foreign Employment, Government of Nepal, Kathmandu.

Durand, J., Kandel, W., Parrado, E.A., Massey, D.S., 1996. International migration and development in Mexican communities. Demography 33, 249-264.

Dustmann, C., Kirchkamp, O., 2002. The optimal migration duration and activity choice after remigration. Journal of development economics 67, 351-372.

Funkhouser, E., 1992. Migration from Nicaragua: some recent evidence. World Development 20, 12091218.

Jadotte, E., 2009. International migration, remittances and labor supply: The case of the Republic of Haiti, 28. Research paper/UNU-WIDER, Helsinki. 
Jeffrey, M.W., 2009. Introductory Econometrics: A modern approach. Canada: South-Western Cengage Learning, Seoul.

Kilic, T., Carletto, C., Davis, B., Zezza, A., 2009. Investing back home Return migration and business ownership in Albania. Economics of Transition 17, 587-623.

Leonard, M., 2000. Coping strategies in developed and developing societies: the workings of the informal economy. Journal of International Development 12, 1069-1085.

McCormick, B., Wahba, J., 2001. Overseas work experience, savings and entrepreneurship amongst return migrants to LDCs. Scottish Journal of Political Economy 48, 164-178.

MOF, 2014. Economic Survey. Ministry of Finance, Government of Nepal. Kathmandu.

MOF., 2015. Economic Survey. Ministry of Finance, Government of Nepal. Kathmandu.

NRB, 2013. Quarterly Economic Bulletin. Nepal Rastra Bank (NRB), Kathmandu.

Rozelle, S., Taylor, J.E., DeBrauw, A., 1999. Migration, remittances, and agricultural productivity in China. The American Economic Review 89, 287-291.

Sapkota, C., 2013. Remittances in Nepal: boon or bane?. The Journal of Development Studies 49, 13161331.

Schoof, U., 2006. Stimulating Youth Entrepreneurship: Barriers and incentives to enterprise start-ups by young people. International Labour Organization, Geneva.

Seddon, D., Adhikari, J., Gurung, G., 2002. Foreign labor migration and the remittance economy of Nepal. Critical Asian Studies 34, 19-40.

Sharma, S., Pandey, S., Pathak, D., Sijapati-Basnett, B., 2014. State of migration in Nepal. Centre for the Study of Labor and Mobility, Kathmandu.

Stark, O., Bloom, D.E., 1985. The new economics of labor migration. The American Economic Review $75,173-178$.

Stark, O., Levhari, D., 1982. On migration and risk in LDCs. Economic Development and Cultural Change 31, 191-196.

Taylor, J.E., Fletcher, P., 2001. Remittances and Development in Mexico: The New Labor Economics of Migration: A Critical Review. Rural Mexico Research Project 2, Mexico.

ThapaParajuli, R. B. (2013). An Inquiry into 'Remittance-Growth'Nexus in Nepal. Nepal's National Interests-II. Foreign Affairs Study Center, Kathmandu.

Tuladhar, R., Sapkota, C., Adhikari, N., 2014. Effects of migration and remittance income on Nepal's agriculture yield. Asian Development Bank, Manila.

Wagner, J., 2005. Nascent necessity and opportunity entrepreneurs in Germany evidence from the regional entrepreneurship monitor (REM). Document de travail 10, 1-24.

The World Bank, 2013. Migration and Entrepreneurship in Nepal with a focus on Youth: An Initial Analysis. The World Bank Group, Kathmandu.

Woodruff, C., Zenteno, R., 2007. Migration networks and microenterprises in Mexico. Journal of Development Economics 82, 509-528. 